\title{
SERBIAN EFL TEACHERS AND LEARNERS' ATTITUDES TO PEER ASSESSMENT AND THE COMPARISON OF TEACHER AND PEER SPEAKING ASSESSMENT SCORES
}

\begin{abstract}
The present paper is inspired by the scarcity of research into the practical implementation of peer assessment in Serbian EFL classrooms. Hence, the study explores the attitudes of Serbian EFL teachers and learners on peer assessment and compares the results of an assessment experiment in which the teachers and students had the task to assess speaking performance according to the predefined speaking assessment guidelines. The research consisted of three parts. The first part included 112 teachers taking part in the questionnaire, while the second part comprised 130 primary and secondary students filling in the relevant survey. The third experimental part involved 24 students and 15 teachers as evaluators, and 5 students as presenters, i.e. the assessed speakers. The results showed generally positive attitudes towards peer assessment both among teachers and learners, with certain reservations underpinned in the study. The assessment experiment results point to the overall agreement of teacher and learner scores, which emphasizes the importance of peer assessment incorporation as relatively reliable classroom assessment practice.
\end{abstract}

Keywords: peer assessment, EFL, Serbian teachers and learners' attitudes.

\section{Introduction}

Relevant teaching methodology literature defines three fundamental formal assessment types, including formative, summative and diagnostic assessment (Hanna \& Dettmer, 2004). Formative assessment, provides feedback and measures students' progress during the very process of learning and includes reviewed homework, class observations or teacher and students' conferences, while more frequently used summative assessment occurs at the end of the learning process summarizing both the teaching and learning process and providing information about the achieved progress, incorporating final examinations, projects, rubrics and portfolios, as well as term papers. Diagnostic assessment identifies students' current

1 E-mail: danicajerotijevic@gmail.com 
level of knowledge and abilities, and it is usually done before the actual learning and teaching takes place, in order to avoid misconceptions and erroneous judgements about students' previously acquired skills, including forms of pre-tests or interviews.

Peer assessment, generally recognized as a part of formative assessment, includes student's feedback on their classmates' performance or on a finished product, sometimes also incorporating grading, even though such evaluation is not highly recommended due to the issues of negative attitude creation, animosity and anxiety level increase (Boud \& Falchikov, 2007). Although the definitions of the concept vary, scholars agree on the complementary roles of self- and peer-assessment, and regard the latter as students' decisions on their peer's work occurring frequently when they collaborate on a project, yet it is not necessarily the obligatory scenario (Black et al., 2004). Contemporary perspectives suggest that favourable assessment should include both formative assessment, i.e. the traditional teacher-oriented form of assessment where they provide feedback and check students' progress during the various stages of learning, and assessment for learning, i.e. the assessment involving student feedback and participation (Stiggins, 2002). Hence, peer assessment application actually provides insight into how willing teachers are to incorporate both formative and assessment for learning, simultaneously exploring the usefulness of the incorporation (Black et al., 2004). Earlier studies used the term peer evaluation alternatively, underlining that evaluation likewise encourages involvement and provides feedback, and teaches responsibility (Weaver \& Cotrell, 1986). However, as we already mentioned, recent studies suggest clear-cut distinction between the two, favouring assessment due to the issues of negative attitude creation and peer animosity.

Inadequate training and lack of knowledge may lead to certain misconceptions about assessment among teachers, reflected in the attitudes that assessment is a test or an average of performances on tests at the end of a learning period, supposedly including what is the easiest to measure, as well as students' behaviour (Earl, 2003; Greenstein, 2010). However, successful implementation of assessment and evaluation strategies assumes clear definitions of learning outcomes, correspondence of assessments with teaching, variability of assessment strategies and encouragement of students' participation in the assessment process, and students' criteria review in order to ensure fairness.

To our knowledge, peer assessment is not a highly frequent practice in Serbian EFL classrooms and in Serbian classrooms in general. However, the importance of successful implementation of peer assessment is evident in developing learner autonomy, while actively participating in the learning process. More traditional approaches regard students as passive listeners, who are supposed to absorb the information and remember it during the test, whereas current approaches emphasize the necessity of cooperation, since it enables students to understand the value of responsibility and reliance on others and mutual contribution to a common goal (Johnson \& Johnson, 1991). Previous studies demonstrated the significance of peer assessment incorporation for the development of e.g. writing skills among Serbian EFL learners (Ljubojević, 2015), hence the possible justification for expanding the use of this assessment technique even in more traditional Serbian classrooms. 
Having the lack of research in the field of peer assessment, and assessment in general, in Serbian EFL scientific context, the present study investigates Serbian EFL teachers and learners' attitudes towards peer assessment and compares the results of the practical implementation of the strategy in question on measuring speaking performance by Serbian EFL teachers and learners.

\section{Previous Investigations on Peer Assessment}

Relevant EFL studies reported on the benefits of peer assessment anew, including, first and foremost, the encouragement of learner autonomy and critical thinking skills development, raising the quality of learning by actively engaging learners in the performance assessment criteria definition, and other students' performance evaluations. Furthermore, peer assessment contributes to the enhancement of motivation and responsibility for their own learning and commitment, by providing feedback and enabling students to model internal assessment of performance. By engaging in peer assessment students get the opportunity to feel as members of the community, to transfer the necessary communicative and professional skills for future application in real life situations (Mills \& Glover, 2006; Orsmond et al., 2002).

Peer assessment is said to have certain shortcomings that we shall address briefly. Namely, the strategy in question carries the risk of unreliability of assessment results due to peer pressure and subjectivity, as well as the tendency of students to reward the same mark to everyone (Brown et al., 1994). Furthermore, there is the potential reluctance of students to assess their peers, feeling unskilled to perform assessment or simply desiring to avoid discrimination (Haaga, 1993). Scholars suggest solutions for overcoming potential peer assessment drawbacks by clearly defining learning goals, carefully preparing students for the task, and enabling anonymous assessment of both performers and assessors (Sims, 1989; Wilson, 2002).

When it comes to the very attitudes of students and teachers to peer assessment, some studies reported on students' positive attitudes (Williams, 1992), while others demonstrated students' disagreement with the implementation of the technique in question as a part of regular assessment (Peters, 1996). Studies generally conclude that students want to be involved in the assessment process, but they like to have predefined criteria and guidelines in order to avoid undesirable outcomes (Williams, 1992). Teachers express negative attitude towards peer assessment if it leads to disagreement and confrontation among students (Nelson \& Carson, 2006), and it is generally believed that it should be avoided if teachers find it unsuitable for their particular classroom conditions (Rubin, 2006).

An extensive body of literature reports on the effects of peer assessment strategy application for other subjects, as well as on teachers' attitudes to it, however, there are fewer investigations dealing with the actual teacher practices and the results of peer assessment implementation in everyday curriculum. For instance, Butler and Hodge explored peer assessment in high school physical education, emphasizing the importance of providing feedback 
on student's performance and increasing trust and reliance on classroom peers (Butler \& Hodge, 2001). Orpen found no difference between teacher and learner assessment (Orpen, 1982), and Somervell claimed that students sometimes have better knowledge of their peers' performance than the very teacher, since they constantly witness their peers' progress (Somervell, 1993). Moreover, Falchikov and Goldfinch, Stefani, as well as Mills and Glover, demonstrated that peer assessment can be as reliable as that of the teacher, increasing thus the level of students' motivation and the eagerness to participate (Falchikov \& Goldfinch, 2000; Mills \& Glover, 2006; Stefani, 1994). In a study on medical students, it was found that peer assessment was consistent, unbiased and valid (Arnold et al., 1981). Other authors emphasized that results may vary depending on certain factors that need to be taken into consideration, such as students' age (Falchikov, 1986). Falchikov and Goldfinch claimed that students and teachers' average marks agree to a significant extent, and that the highest correlation between their ratings would be achieved provided that several factors were combined, such as precisely defined criteria of judgment, pre-studied assessment procedure and a satisfactory academic task (Falchikov \& Goldfinch, 2000). Noonan and Duncan believe that the most important areas of research should include the extent of student involvement and teacher participation in peer-assessment, and the ways in which the strategy enhances the learning process (Noonan \& Duncan, 2005).

\section{Method}

\section{The Aim of the Study}

The aim of the current study was to investigate Serbian EFL teachers and learners' attitudes towards peer assessment and to compare speaking assessment results of teachers and learners, more precisely, to compare peer assessment and teacher assessment scores on the speaking assessment experiment.

\section{Research Questions}

- The present research is based on the following research questions:

- What are Serbian EFL teachers' attitudes to peer assessment?

- What are Serbian EFL students' attitudes to peer assessment?

- Are there any similarities or differences in the speaking assessment scores obtained from teachers and students? Hence, can peer assessment be regarded as a valid assessment technique in Serbian EFL classrooms?

\section{Participants}

The chosen sample comprised 112 teachers for the first segment of the research, i.e. 112 teachers from Belgrade, Požarevac, Jagodina, Ćuprija, Paraćin, Gornji Milanovac, Kragujevac and Niš participated in the survey. Descriptive statistics for the sample of teachers can be found in Table 1. 
Jerotijević Tišma, D. • Serbian EFL teachers and learners' attitudes... • НВ год. LXV бр. 2/2016, стр. 379-393.

Table 1. Descriptive statistics for the chosen sample of teachers for the questionnaire (\%)

\begin{tabular}{|c|c|c|c|}
\hline Gender & Level of Education & Teaching Experience (years) & Level of Education Taught \\
\hline $\begin{array}{ll}\text { Male } & 26(23.2) \\
\text { Female } & 86(76.8)\end{array}$ & $\begin{array}{lc}\text { B.A } & 30(26.8) \\
\text { M.A. } & 78(69.6) \\
\text { PhD } & 4(3.6)\end{array}$ & $\begin{array}{lc}0-5 & 54(48.2) \\
5-10 & 24(21.4) \\
10-20 & 25(22.3) \\
\text { Over 20 } & 9(8.0)\end{array}$ & $\begin{array}{r}1-4^{\text {th }} \text { grade Elementary } \\
33(29.5) \\
5-8^{\text {th }} \text { grade Elementary } \\
26(23.2) \\
1-4^{\text {th }} \text { grade Secondary } \\
49(43.8) \\
\text { Undergraduate students } \\
4(3.6)\end{array}$ \\
\hline St.dev. 0.424 & St.dev. 0.502 & St.dev. 1.013 & St.dev. 0.915 \\
\hline
\end{tabular}

Concerning the second part of the study, a total of 130 students, 62 from primary and 68 from secondary schools in Jagodina completed the questionnaire. Primary school students were sampled from the $8^{\text {th }}$ grade: mean age $13.93 ; 15$ male, 12 female.

Finally, 24 students and 15 teachers participated in the third part of the research, i.e. in the assessment experiment as assessors, and 5 students as presenters, or the evaluated party. The students chosen for peer assessment belonged to the same class as presenters, $4^{\text {th }}$ grade of the secondary school, mean age 17.79, 9 male, 15 female, whereas the presenters were all female, mean age 17.6. The teachers were chosen based on their answers on the questionnaire, i.e. based on whether their acquaintance with the peer assessment technique and frequency of practical application. The descriptive statistics of the sample of teachers can be seen in table 2 .

Table 2. Descriptive statistics for the chosen sample of teachers for the assessment experiment (\%)

\begin{tabular}{|c|c|c|c|c|}
\hline Gender & Level of Education & \begin{tabular}{|l} 
Teachi \\
(years)
\end{tabular} & perience & Level of Education Taught \\
\hline \begin{tabular}{|ll} 
Male & $4(26.7)$ \\
Female & $11(73.3)$
\end{tabular} & $\begin{array}{l}\text { B.A } 3(20.0) \\
\text { M.A. } 12(80.0)\end{array}$ & $\begin{array}{l}0-5 \\
5-10 \\
10-20\end{array}$ & $\begin{array}{l}8(53.3) \\
4(26.7) \\
3(20.0)\end{array}$ & $\begin{array}{l}1-4^{\text {th }} \text { grade Elementary } \\
2(13.3) \\
5-8^{\text {th }} \text { grade Elementary } \\
7(46.7) \\
1-4^{\text {th }} \text { grade Secondary } \\
6(40.0)\end{array}$ \\
\hline St.dev. 0.458 & St.dev. 0.414 & St.dev. & & St.dev. 0.704 \\
\hline
\end{tabular}

\section{Instruments}

The primary instruments for the present examination were two forms of questionnaires for teachers and students with five-point Likert scales, and an assessment sheet for the third part of the experiment. The questionnaire form for teachers was adapted from a previous study dealing with a similar topic (Wen et al., 2006: 89), and the students' questionnaire was adapted from two previous studies (Azarnoosh 2013: 6; Peng 2010: 95). 
The assessment sheet that was distributed to students for peer assessment, and to teachers for speaking evaluations of presenters, was a combination of a modified assessment sheet from a previous study (Peng 2010: 104-105) and Cambridge English Language Assessment for B1/B2 level CEFR ${ }^{2}$ recommendations. The instructions for assessment were provided prior to the experimental period and were thoroughly explained to ensure understanding. Each of the segments in the assessment rubrics contained a precise description of what is expected.

\section{Procedure}

The examination in question consisted of three parts.

In the first part we conducted a survey investigating Serbian teachers' attitudes to peer assessment in order to gain insight into how common and favourable this form of assessment is in Serbian EFL classrooms, hence we included teachers at various levels of education with different amount of teaching experience.

The second part included a questionnaire done by Serbian EFL primary and secondary school students, likewise investigating attitudes, yet this time students' attitudes towards peer assessment. All the questionnaires were distributed personally or via email.

In the third part we performed an assessment experiment in which we aimed at practically applying peer assessment technique and comparing the results to the most common assessment technique, teacher assessment. The task was to assess students' speaking performance during the in-class presentations on the topic "People and Culture of (country of their own choice)". The students gave marks from 1 to 5 , but each mark had an assigned comment, representing feedback on performance with short description for each of the mark. The numbers from 1 to 5 did not actually represent grades, but quantifiable feedback, for the purpose of better presentation and easier calculation and comparison. In this way we wanted to avoid unrecommendable grading of students by their peers, and the resulting anxiety and potential animosity. We could say that our experiment thus combines peer assessment and peer evaluation, even though the outcome is a single mark. There were five speakers to be assessed, i.e. five presentations overall. The presenters had the freedom to use any available material within the allocated 20 minutes for presentation. The speakers were assessed by the peers during the very presentation, while they were recorded using Canon Powershot G3X digital camera for later evaluation by the teachers participating in the experiment to avoid anxiety issues and ensure natural classroom environment. The recordings of the presentations were later played to the teachers individually or in smaller groups. Both the teachers and the students received the same assessment instructions and rubrics to ensure validity of the testing instruments.

The survey and experimental part of the research continued from September to March 2014/2015 school year. A preliminary investigation, i.e. a small scale pilot experiment was performed in December 2011, incorporating one teacher and 15 students of

2 The assessment sheet and recommendations can be found on http://www.cambridgeenglish. org/exams/first/results/ 
the same class at the third year of the secondary level of education assessing two speakers (S1, S2), mark scale 1-5 (1 - poor; 5 - excellent). The assessment sheet included fewer segments than the one used in the current experiment, yet the results can be seen in Table 3. The results of student's t-test demonstrated that the difference between students and teachers' assessment scores was not statistically significant, hence we wanted to increase the number of participants and repeat the measurements.

Table 3. Results of the speaking assessment of the pilot experiment done in 2011

\begin{tabular}{|c|c|c|c|c|c|c|}
\hline \multicolumn{2}{|c|}{ Participants } & \multirow{2}{*}{$\begin{array}{c}\begin{array}{c}\text { Grammar and } \\
\text { Vocabulary }\end{array} \\
4.33\end{array}$} & \multirow{2}{*}{$\begin{array}{c}\begin{array}{c}\text { Pronunciation } \\
\text { and Clarity }\end{array} \\
2.93\end{array}$} & \multirow{2}{*}{$\begin{array}{c}\begin{array}{c}\text { Quality } \\
\text { of Content }\end{array} \\
3.2\end{array}$} & \multirow{2}{*}{ 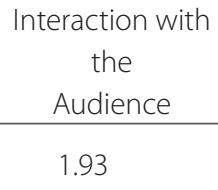 } & \multirow{2}{*}{ t-test scores } \\
\hline \multirow{2}{*}{ Students } & S1 & & & & & \\
\hline & S2 & 4.93 & 4.8 & 4.6 & 3.5 & \multirow{3}{*}{$\begin{array}{l}p=0.4788 \\
t=0.7276 \\
d f=14 \\
\text { standard error of } \\
\text { difference }=0.478\end{array}$} \\
\hline \multirow{2}{*}{ Teacher } & S1 & 4 & 3 & 5 & 3 & \\
\hline & $\mathrm{S} 2$ & 5 & 5 & 4 & 4 & \\
\hline
\end{tabular}

\section{Data Analysis}

Statistical data processing necessary for the current research was performed using IBM SPSS Statistics program, version 20.0, including descriptive statistics, frequency counts and student's t-test.

\section{Results and Discussion}

\section{Results of the Questionnaire on Serbian EFL Teachers' Attitudes to Peer Assessment}

Before the segment of the survey containing statements with Likert scale answers, the questionnaire contained two questions regarding teachers' familiarity with the notion of peer assessment and the frequency of its application. The majority of teachers (78 or $69.6 \%$ ) said that they had heard about peer assessment, but did not know many details, and about one fourth of teachers claimed that they were very familiar with the notion (27 or $24.1 \%$ ). 7 respondents (or 6.3\%) answered that they were not acquainted with peer assessment technique. About a half of the teachers said that they rarely used peer assessment (49 or $43.8 \%$ ) and 32 respondents said that they never used this technique (32 or $28.6 \%$ ). The encouraging 23 respondents (or 20.5\%) said they used it occasionally and 8 (or $7.1 \%$ ) respondents said they frequently used the technique in question. Table 4 presents the results of the rest of the questionnaire. 
Jerotijević Tišma, D. • Serbian EFL teachers and learners' attitudes... • НВ год. LXV 6р. 2/2016, стр. 379-393.

Table 4. Serbian EFL Teachers' Attitudes to Peer Assessment

\begin{tabular}{|c|c|c|c|c|c|}
\hline Statement & $\begin{array}{c}\text { Strongly } \\
\text { Agree }\end{array}$ & Agree & $\begin{array}{l}\text { Not } \\
\text { Sure }\end{array}$ & $\begin{array}{c}\text { Dis- } \\
\text { agree }\end{array}$ & $\begin{array}{l}\text { Strongly } \\
\text { Disagree }\end{array}$ \\
\hline $\begin{array}{l}\text { Peer assessment is helpful to students'learn- } \\
\text { ing. }\end{array}$ & $\begin{array}{c}47 \\
(42.0 \%)\end{array}$ & $\begin{array}{c}28 \\
(25.0 \%)\end{array}$ & $\begin{array}{c}30 \\
(26.8 \%)\end{array}$ & $\begin{array}{c}7 \\
(6.3 \%)\end{array}$ & / \\
\hline $\begin{array}{l}\text { Peer assessment makes students understand } \\
\text { more about teacher's requirements. }\end{array}$ & $\begin{array}{c}50 \\
(44.6 \%)\end{array}$ & $\begin{array}{c}43 \\
(38.4 \%)\end{array}$ & $\begin{array}{c}12 \\
(10.7 \%)\end{array}$ & $\begin{array}{c}7 \\
(6.3 \%)\end{array}$ & / \\
\hline $\begin{array}{l}\text { Peer assessment activities motivate students } \\
\text { to learn. }\end{array}$ & $\begin{array}{c}37 \\
(33.0 \%)\end{array}$ & $\begin{array}{c}43 \\
(38.4 \%)\end{array}$ & $\begin{array}{c}26 \\
(23.2 \%)\end{array}$ & $\begin{array}{c}6 \\
(5.4 \%)\end{array}$ & / \\
\hline $\begin{array}{l}\text { Peer assessment activities increase the } \\
\text { interaction between the teacher and the } \\
\text { students. }\end{array}$ & $\begin{array}{c}11 \\
(9.8 \%)\end{array}$ & $\begin{array}{c}44 \\
(39.3 \%)\end{array}$ & $\begin{array}{c}42 \\
(37.5 \%)\end{array}$ & $\begin{array}{c}11 \\
(9.8 \%)\end{array}$ & $\begin{array}{c}4 \\
(3.6 \%)\end{array}$ \\
\hline $\begin{array}{l}\text { Peer assessment helps students develop a } \\
\text { sense of participation. }\end{array}$ & $\begin{array}{c}69 \\
(61.6 \%)\end{array}$ & $\begin{array}{c}40 \\
(35.7 \%)\end{array}$ & $\begin{array}{c}3 \\
(2.7 \%) \\
\end{array}$ & / & / \\
\hline $\begin{array}{l}\text { Peer assessment activities increase the } \\
\text { interaction among students. }\end{array}$ & $\begin{array}{c}59 \\
(52.7 \%)\end{array}$ & $\begin{array}{c}43 \\
(38.4 \%)\end{array}$ & $\begin{array}{c}10 \\
(8.9 \%)\end{array}$ & / & I \\
\hline $\begin{array}{l}\text { Students are eligible to assess their } \\
\text { classmates' performance. }\end{array}$ & $\begin{array}{c}7 \\
(6.3 \%) \\
\end{array}$ & $\begin{array}{c}33 \\
(29.5 \%)\end{array}$ & $\begin{array}{c}36 \\
(32.1 \%)\end{array}$ & $\begin{array}{c}21 \\
(18.8 \%)\end{array}$ & $\begin{array}{c}15 \\
(13.4 \%)\end{array}$ \\
\hline Peer assessment is reliable. & $\begin{array}{c}7 \\
(6.3 \%) \\
\end{array}$ & $\begin{array}{c}39 \\
(34.8 \%)\end{array}$ & $\begin{array}{c}40 \\
(35.7 \%)\end{array}$ & $\begin{array}{c}19 \\
(17.0 \%)\end{array}$ & $\begin{array}{c}7 \\
(6.3 \%) \\
\end{array}$ \\
\hline $\begin{array}{l}\text { Peer assessment can be used as part of the } \\
\text { final mark decision making process only } \\
\text { along with teacher's assessment tools. }\end{array}$ & $\begin{array}{c}55 \\
(49.1 \%)\end{array}$ & $\begin{array}{c}57 \\
(50.9 \%)\end{array}$ & / & / & / \\
\hline $\begin{array}{l}\text { Anonymous peer assessment is more } \\
\text { suitable than an open one. }\end{array}$ & $\begin{array}{c}33 \\
(29.5 \%) \\
\end{array}$ & $\begin{array}{c}44 \\
(39.3 \%) \\
\end{array}$ & $\begin{array}{c}21 \\
(18.8 \%)\end{array}$ & $\begin{array}{c}10 \\
(8.9 \%) \\
\end{array}$ & $\begin{array}{c}4 \\
(3.6 \%) \\
\end{array}$ \\
\hline $\begin{array}{l}\text { Peer assessment can be useful for improving } \\
\text { speaking skills. }\end{array}$ & $\begin{array}{c}47 \\
(42.0 \%) \\
\end{array}$ & $\begin{array}{c}58 \\
(51.8 \%) \\
\end{array}$ & $\begin{array}{c}7 \\
(6.3 \%) \\
\end{array}$ & / & / \\
\hline $\begin{array}{l}\text { Peer assessment can be useful in improving } \\
\text { writing skills. }\end{array}$ & $\begin{array}{c}22 \\
(19.5 \%) \\
\end{array}$ & $\begin{array}{c}71 \\
(63.4 \%) \\
\end{array}$ & $\begin{array}{c}18 \\
(16.1 \%)\end{array}$ & $\begin{array}{c}1 \\
(0.9 \%) \\
\end{array}$ & / \\
\hline $\begin{array}{l}\text { Peer assessment can be useful in improving } \\
\text { pronunciation. }\end{array}$ & $\begin{array}{c}8 \\
(7.1 \%)\end{array}$ & $\begin{array}{c}34 \\
(30.4 \%)\end{array}$ & $\begin{array}{c}65 \\
(58.0 \%)\end{array}$ & $\begin{array}{c}5 \\
(4.5 \%)\end{array}$ & / \\
\hline
\end{tabular}

More than $60 \%$ of the teachers believes that peer assessment can be helpful to learning, and the significantly larger percentage believes that peer assessment facilitates teacher requirements comprehension (about 83\%). The participants in the survey likewise agree that peer assessment can be motivating (more than 60\%), however, around $40 \%$ of teachers only states that the technique in question could increase the interaction between the teacher and the students. The most favorable characteristics of peer assessment by Serbian EFL teachers seems to be its ability to develop students' sense of participation and increase the interaction among the very students, since about $90 \%$ of teachers agrees with both. Nevertheless, the main problem in allowing students to assess each other's performance, for our examinees at least, seems to be the lack of reliability and eligibility on the part of students, since only about $40 \%$ of teachers believe students are a valid source of information 
about their peers' knowledge evaluation. All the teachers think that peer assessment should be used as part of the final mark decision making process exclusively together with teacher's assessment tools, which goes in line with the stated issues with reliability and eligibility of students. Around $68 \%$ of the participants agree that anonymous peer assessment would be more appropriate than an open one. Regarding the influence of peer assessment on the improvement of specific skills, the majority of teachers believes that peer assessment can enhance speaking (around 93\%) and writing (about 82\%), but they are not sure whether it can affect pronunciation performance (58\% are not sure).

Overall, we could conclude that Serbian EFL teachers have a generally positive attitude towards peer assessment, which is in collision with the fact that about $70 \%$ of teachers say they rarely or never apply the technique practically.

\section{Results of the Questionnaire on Serbian EFL Students' Attitudes to Peer Assessment}

The results of the questionnaire related to the attitudes of Serbian EFL learners towards peer assessment are presented in Table 5.

Table 5. Serbian EFL Learners' Attitudes to Peer Assessment

\begin{tabular}{|l|c|c|c|c|c|}
\hline Statement & $\begin{array}{c}\text { Strongly } \\
\text { Agree }\end{array}$ & Agree & Not Sure & Disagree & $\begin{array}{c}\text { Strongly } \\
\text { Disagree }\end{array}$ \\
\hline $\begin{array}{l}\text { Peer assessment is helpful to } \\
\text { my learning. }\end{array}$ & $\begin{array}{c}48 \\
(36.9 \%)\end{array}$ & $\begin{array}{c}32 \\
(24.6 \%)\end{array}$ & $\begin{array}{c}29 \\
(22.3 \%)\end{array}$ & $\begin{array}{c}10 \\
(7.7 \%)\end{array}$ & $(8.5 \%)$ \\
\hline Peer assessment makes me understand & 32 & 40 & 21 & 24 & 13 \\
more about teacher's requirements. & $(24.6 \%)$ & $(30.8 \%)$ & $(16.2 \%)$ & $(18.5 \%)$ & $(10.0 \%)$ \\
\hline Peer assessment can help me improve & 27 & 39 & 37 & 17 & 10 \\
my speaking skills. & $(20.8 \%)$ & $(30.0 \%)$ & $(28.5 \%)$ & $(13.1 \%)$ & $(7.7 \%)$ \\
\hline Peer assessment is reliable. & 18 & 43 & 31 & 27 & 11 \\
& $(13.8 \%)$ & $(33.1 \%)$ & $(23.8 \%)$ & $(20.8 \%)$ & $(8.5 \%)$ \\
\hline Peer assessment is difficult. & 9 & 26 & 7 & 63 & 25 \\
& $(6.9 \%)$ & $(20.0 \%)$ & $(5.4 \%)$ & $(48.5 \%)$ & $(19.2 \%)$ \\
\hline Peer assessment is interesting. & 49 & 52 & 1 & 23 & 5 \\
& $(37.7 \%)$ & $(40.0 \%)$ & $(0.8 \%)$ & $(17.75 \%)$ & $(37.7 \%)$ \\
\hline Peer assessment is motivating. & 35 & 40 & 44 & 8 & 3 \\
& $(26.9 \%)$ & $(30.8 \%)$ & $(33.8 \%)$ & $(6.2 \%)$ & $(2.3 \%)$ \\
\hline Peer assessment helps students develop & 48 & 41 & 18 & 17 & 6 \\
a sense of participation. & $(36.9 \%)$ & $(31.5 \%)$ & $(13.8 \%)$ & $(13.1 \%)$ & $(4.6 \%)$ \\
\hline Peer assessment activities increase & 46 & 53 & 25 & 4 & 2 \\
the interaction among students. & $(35.4 \%)$ & $(40.8 \%)$ & $(19.2 \%)$ & $(3.1 \%)$ & $(1.5 \%)$ \\
\hline Students are eligible to assess their & 20 & 48 & 41 & 12 & 9 \\
classmates' performance. & $(15.4 \%)$ & $(36.9 \%)$ & $31.5 \%)$ & $(9.2 \%)$ & $(6.9 \%)$ \\
\hline
\end{tabular}

Slightly above $50 \%$ of students believes that peer assessment is helpful to learning, which is similar to the results by the teachers, yet we should note that students' percentage 
is a little lower. However, the difference between teacher and students' results is even more evident in the second statement, namely about $20 \%$ less students believe that peer assessment facilitates comprehension of teacher's requirements. The students likewise agree with the teachers that peer assessment is not completely reliable and that students are not eligible to assess other students (only about $40 \%$ believes the opposite, the rest of them are either not sure or disagree), although they think it may help them improve their speaking skills (around 50\%). The students believe that peer assessment can be interesting (around 77\%) and motivating (about 56\%), and they do not find it difficult (around $67 \%$ ), which likewise corresponds to the answers given by teachers. Again similarly to teachers, the students claim that peer assessment helps students develop a sense of participation (about 68\%) and increases interaction among students (about 75\%).

\section{Results of the Comparison of Teacher and Peer Speaking Assessment}

The assessment rubric for speaking assessment included: a segment on how the presentation was structured, i.e. whether it was clear, coherent, logically organized and presented; pronunciation and overall clarity of expression in which the evaluators had to decide on the speakers' general intelligibility, pronunciation accuracy, intonation and the degree of foreign accent; a segment on proper grammar and vocabulary use and the diversity of lexical expressions; a segment on the quality of the content, i.e. how useful and practically applicable the content of the presentation is; a segment on how the presenter interacted with the audience including their confidence, eye contact, the loudness of voice, emphasis on important parts and bogy language and gestures; and finally a segment on timing and pacing of the whole presentation, i.e. how well it fit the prescribed time frame. Hence, the participants in the experiment suggested their marks for each of the five speakers presenting their favourite culture and nation.

If we compare teachers and students' results, we notice that there are no statistically significant differences in the scores, i.e. students' assessment almost completely agrees with the teachers' evaluation of the speaking performance of the five presenters (t-testing suggests no statistically significant difference whatsoever, $p=0.94, t=0.0746$ ). This may lead us to infer that peer assessment could be used as a valid form of speaking performance assessment in Serbian EFL classrooms more often, since it is eligible and fairly reliable, having in mind that the results agree to the teachers' marks, if we are to regard teachers' marks as objective, valid, reliable and eligible means of students' performance assessment.

There are slight distinctions between teachers and students, however, in individual marks pertaining to individual speakers and separate segments of the evaluation rubric. Generally speaking, the differences in marks do not have a clear and consistent pattern, they prevailingly depend on an individual speakers' performance, yet they do not diverge extremely, which is likewise important in terms of eligibility and reliability, and the mutual distrust related to assessment. 
Jerotijević Tišma, D. • Serbian EFL teachers and learners' attitudes... • НВ год. LXV бр. 2/2016, стр. 379-393.

Table 6. Teachers and Students' Average Marks on the Speaking Assessment Experiment

\begin{tabular}{|c|c|c|c|c|c|c|c|c|c|c|}
\hline \multirow[t]{2}{*}{ Assessment Rubrics } & \multicolumn{5}{|c|}{ Teachers' Average Mark } & \multicolumn{5}{|c|}{ Peer Assessment Average Mark } \\
\hline & S1 & S2 & S3 & S4 & S5 & S1 & S2 & S3 & S4 & S5 \\
\hline Structure of the Presentation & 4.27 & 3.0 & 5.0 & 3.47 & 4.67 & 4.54 & 2.96 & 5.0 & 3.38 & 4.67 \\
\hline $\begin{array}{l}\text { Pronunciation and Clarity } \\
\text { of Expression }\end{array}$ & 4.33 & 2.73 & 4.93 & 3.07 & 4.6 & 4.2 & 2.62 & 4.92 & 3.13 & 4.71 \\
\hline $\begin{array}{l}\text { Appropriate/Accurate Use } \\
\text { of Grammar and Vocabulary }\end{array}$ & 3.27 & 3.27 & 4.93 & 2.53 & 3.67 & 3.54 & 2.95 & 4.92 & 2.79 & 4.0 \\
\hline Quality of the Content & 4.07 & 3.73 & 4.93 & 3.86 & 4.53 & 3.75 & 3.25 & 4.58 & 3.63 & 4.54 \\
\hline $\begin{array}{l}\text { Interaction with the } \\
\text { Audience, Confidence } \\
\text { (Eye Contact/Voice/Gestures) }\end{array}$ & 3.6 & 3.93 & 4.33 & 3.27 & 4.4 & 3.75 & 3.92 & 4.54 & 2.79 & 4.46 \\
\hline Timing and Pacing & 5.0 & 3.6 & 5.0 & 4.0 & 4.6 & 4.79 & 3.75 & 4.96 & 3.96 & 4.58 \\
\hline Total & 4.09 & 3.38 & 4.85 & 3.37 & 4.41 & 4.1 & 3.25 & 4.82 & 3.28 & 4.49 \\
\hline $\begin{array}{l}\text { Students't-test scores } \\
\mathrm{p}=0.94 \quad \mathrm{t}=0.0746 \quad \mathrm{df}=8\end{array}$ & & & & & & & & & & \\
\hline
\end{tabular}

Similar scores on the assessment experiment underline several significant conclusions about the application of peer assessment in Serbian EFL classrooms. Namely, the investigated assessment technique can be a useful means of increasing students and teachers' communication and relationship, since it allows students' to contribute to teachers' tasks, and not only the other way around. In this way students get the feeling that their opinion is respected and adhered to, which further enhances motivation and eagerness to learn and participate in classroom activities. Moreover, allowing students to decide on their peer's mark ensures, or at least advances the objectivity of final assessment, and decreases or completely omits the possibility of students' having doubts regarding teachers' subjectivity and personal preference especially regarding speaking performance assessment. Understandably, peer assessment should be carefully planned and students' proficiency level and age should be taken into consideration, in order to ensure validity of the results.

Serbian teachers generally exhibit a positive attitude towards including peer assessment in EFL classroom, which disagrees with some previous findings (Nelson \& Carson, 2006; Rubin, 2006; Wang \& Wu, 2008), yet the expressed doubts about the reliability of students' assessment confirms previous findings from the afore mentioned studies.

The results of the students' attitudes survey generally agree with the previous studies (Orsmond et al., 1996; Williams, 1992), however, the question of difficulty disagrees with the findings of a previous study by Strachan and Wilcox (Strachan \& Wilcox, 1996). Generally positive attitudes by Serbian EFL learners towards the implementation of peer assessment likewise disagree with the results of a study by Peters (Peters, 1996).

Nevertheless, the results of the experiment, and the correlative ratings of speaking performance by Serbian EFL learners and teachers agree with the conclusions in several previous studies (Falchikov \& Goldfinch, 2000; Mills \& Glover, 2006; Orpen, 1982; Peng, 2010). 


\section{Conclusion}

After a brief theoretical background presented in the introductory segments of the paper, the results of the current research were presented and discussed. The aim of the present investigations was to discover Serbian EFL teachers and learners' attitudes towards peer assessment, as well as to compare the results of teachers and students' speaking assessment suggestions. The research consisted of two questionnaires for students and teachers, and the third, experimental part in which both teachers and students offered their marks and feedback for five speakers' oral proficiency assessment.

The results of the questionnaire point to the general agreement among teachers and students, i.e. they share the positive attitude towards the use of peer assessment, especially in terms of its benefits on motivation and participation enhancement. However, both teachers and students express queries regarding the reliability and eligibility of peer assessment. Comparing teachers and students' speaking assessment marks, we detected no statistically significant difference, consequently concluding that peer assessment may be used as one of the assessment techniques in Serbian EFL classrooms, presuming previous careful planning and cautious application and interpretation of results.

Having the conceptual and practical differences of Serbian and Western European EFL curriculum in mind, several pedagogical implications of the conducted research may be underscored. Namely, the implementation of peer assessment could emphasize learner autonomy and enhance active participation. The lack of trust in the technique is possibly related to the scarce use of peer assessment, thus more frequent application may lead to a more favorable attitudes of both students and teachers to the very technique. By empowering students to take control in the assessment process, teachers may create an atmosphere of interdependence, reliability and responsibility throughout the process of learning. Students' contribution may reduce negative feelings resulting from non-participation. Furthermore, the introduction of an innovative way of evaluating students' work, may likewise contribute to the increase of motivation and replenish everyday classroom routine.

The present research has several notable limitations, pertaining mostly to the design of the research instruments and the number and choice of participants, especially regarding the third segment of research. More precisely, the choice of different proficiency level might have yielded different results and offered more interesting insights.

Hence, there are several suggestions to be had in mind for potential further research. Assessment experiment should include other skills assessment, as well, not only speaking. Students should be allowed to assess writing and listening, to gain more objective insight into the relationship between teachers and students' evaluation, thus increasing the reliability of the claims that peer assessment can be a valid and referential tool in EFL classrooms. Future research should likewise attempt at discovering the reasons behind the existing distrust among both teachers and students related to the reliability of students' assessment. 


\section{References}

Arnold, L., Willoughby, L., Calkins, V., Gammon, L. \& Eberhart G. (1981). Use of Peer Evaluation in the Assessment of Medical Students. Journal of Medical Education, Vol. 56, No. 1, 35-42.

Azarnoosh, M. (2013). Peer Assessment in an EFL Context: Attitudes and Friendship Bias. Language Testing in Asia, Vol. 11, No. 3, 1-10.

Black, P., Harrison, C., Lee, C., Marshall, B. \& Wiliam, D. (2004). Working inside the Black Box: Assessment for Learning in the Classroom. Phi Delta Kappan, Vol. 86, No. 1, 13-22.

Boud, D. \& Falchikov, N. (2007). Rethinking Assessment in Higher Education. London: Kogan Page.

Brown, S., Rust, C. \& Gibbs, G. (1994). Involving Students in the Assessment Process. Strategies for Diversifying Assessments in Higher Education. Retrieved February 23, 2016 from the World Wide Web http://www.lgu.ac.uk/deliberations/ocsd-pubs/div-ass5.html.

Butler, S A. \& Hodge, S. R. (2001). Enhancing Student Trust through Peer Assessment in Physical Education. Physical Educator, Vol. 58, No. 1, 30-42.

Earl, L., (2003). Assessment as Learning: Using Classroom Assessment to Maximize Student Learning. Thousand Oaks: Corwin Press, INC.

Falchikov, N. (1986). Product Comparisons and Process Benefits of Peer Group and Self-Assessments. Assessment and Evaluation in Higher Education, Vol. 11, No. 2, 146-166.

Falchikov, N. \& Goldfinch, J. (2000). Student Peer Assessment in Higher Education: A Meta-Analysis Comparing Peer and Teacher Marks. Review of Educational Research. Vol. 70, No. 3, 287-323.

Greenstein, L., (2010). What Teachers Really Need to Know about Formative Assessment. Cheltenham: Hawker Brownlow Education.

Haaga, D.A.F. (1993). Peer Review of Term Papers in Graduate Psychology Courses. Teaching of Psychology, Vol. 20, No. 1, 28-32.

Hanna, G. S.\& Dettmer, P. A. (2004). Assessment for Effective Teaching:Using Context-Adaptive Planning. Boston: Pearson A \& B.

Johnson, D.W. \& Johnson, R.T. (1991). Cooperation in the Classroom. Edina: Interaction Book Company.

Ljubojević, D. (2015). Razvoj veštine akademskog pisanja na engleskom kao stranom jeziku pomoću alata za saradničko učenje i ocenjivanje (doktorska disertacija). Beograd: Filološki fakultet Univerziteta u Beogradu.

Mills, J. \& Glover, C. (2006). Using Assessment within Course Structure to Drive Student Engagement with the Learning Process. Retrieved January 18, 2016 from the World Wide Web www.open.ac.uk/fast.

Nelson, G. \& Carson, J. (2006). Cultural Issues in Peer Response: Revisiting "Culture". In K. H. F. Hyland (Ed.), Feedback in Second Language Writing: Contexts and Issues (pp. 42-54). Cambridge and New York: Cambridge University Press.

Noonan, B. \& Duncan, C. R. (2005). Peer and Self-Assessment in High Schools. Practical Assessment Research \& Evaluation, Vol. 10, No. 7, 1-8.

Orpen, C. (1982). Student versus Lecturer Assessment of Learning: A Research Note. Higher Education, Vol. 11, No. 5, 567-572.

Orsmond, P., Merry, S. \& Reiling, K. (1996). The Importance of Marking Criteria in the Use of Peer Assessment. Assessment and Evaluation in Higher Education, Vol. 21, No. 3, 239-249. 
Orsmond, P., Merry, S. \& Reiling, K. (2002). The Use of Exemplars and Formative Feedback when Using Student Derived Marking Criteria in Peer and Self-Assessment. Assessment and Evaluation in Higher Education. Vol. 27, No. 4, 309-323.

Peng, J. (2010). Peer Assessment in an EFL Context: Attitudes and Correlations. In M. T. Prior, Y. Watanabe \& S. Lee (Eds.), Selected Proceedings of the 2008 Second Language Research Forum (pp. 89-107). Somerville: Cascadilla Proceedings Project.

Peters, M. (1996). Student Attitudes to Alternative Forms of Assessment and to Openness. Open Learning, Vol. 11, No. 3, 48-50.

Rubin, R. S. (2006). The Academic Journal Review Process as a Framework for Student Developmental Peer Feedback. Journal of Management Education, Vol. 30, No. 2, 378-398.

Sims, G. K. (1989). Student Peer Review in the Classroom: A Teaching and Grading Tool. Journal of Agronomic Education, Vol. 8, No. 2,105-108.

Somervell, H. (1993). Issues in Assessment, Enterprise and Higher Education: The Case for Self, Peer and Collaborative Assessment. Assessment \& Evaluation in Higher Education, Vol.18, No. 3, 221233.

Stefani, L.A.J. (1994). Peer, Self and Tutor Assessment: Relative Reliabilities. Studies in Higher Education, Vol. 19, No. 1, 69-75.

Stiggins, R. J. (2002). Assessment Crisis: The Absence of Assessment for Learning. Phi Delta Kappan. Vol. 83, No. 10, 758-765.

Strachan, I. B. \& Wilcox, S. (1996). Peer and Self Assessment of Group Work: Developing an Effective Response to Increased Enrollment in a Third Year Course in Microclimatology. Journal of Geography in Higher Education, Vol. 20, No. 3, 343-353.

Wang, S. L. \& Wu, P. Y. (2008). The Role of Feedback and Self-Efficacy on Web-Based Learning: The Social Cognitive Perspective. Computers Camp Education, Vol. 51, No. 4, 1589-1598.

Weaver, R. L. \& Cotrell, H.W. (1986). Peer Evaluation: A Case Study. Innovative Higher Education, Vol. 11 , No. 1, 25-39.

Wen, M., Tsai, C. \& Chang, C. (2006). Attitudes towards Peer Assessment: A Comparison of the Perspectives of Pre-Service and In-Service Teachers. Innovations in Education and Teaching International, Vol. 43, No. 1, 83-92.

Williams, E. (1992). Student Attitudes towards Approaches to Learning and Assessment. Assessment and Evaluation in Higher Education, Vol. 17, No. 1, 45-58.

Wilson, S. (2002). Comparing Peer, Self and Tutor Assessment in a Course for University Teaching Staff. In Learning Communities and Assessment Cultures Conference, Full Papers, August 28-30, 2002, Northumbria (pp. 28-30). Northumbria: EARLI Special Interest Group on Assessment and Evaluation, University of Northumbria. 


\title{
СТАВОВИ СРПСКИХ НАСТАВНИКА И УЧЕНИКА ЕНГЛЕСКОГ КАО СТРАНОГ ЈЕЗИКА ПРЕМА ВРШЬАЧКОМ ОЦЕЊИВАЊУ И ПОРЕЪЕЊЕ РЕЗУЛТАТА НАСТАВНИЧКОГ И ВРШЊАЧКОГ ОЦЕЊИВАЊА ГОВОРНЕ КОМПЕТЕНЦИЈЕ
}

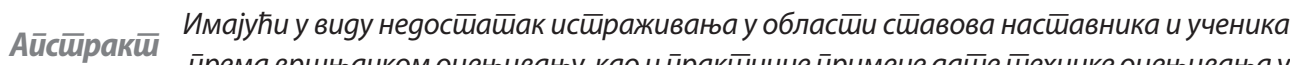
йрема вршњачком оцењивању, као и ӣракишине ӣримене gаше шехнике оцењивањ у у

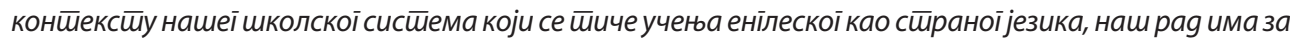

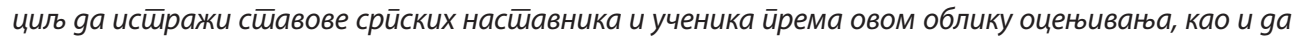
уйореgи резулйайе оцењивања вешйине іовора, ояносно конверзације, уз унайреg gайе и обја-

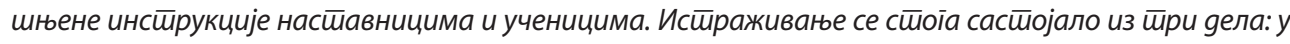
ӣрвом gелу је анкеш̄ирано 112 насйавника, gок је у gруїом 130 ученика основних и среgюих школа ӣо-

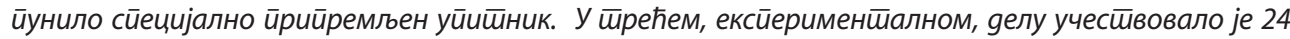

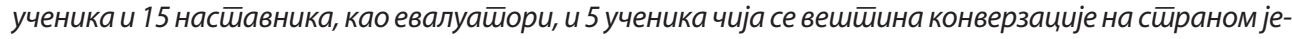

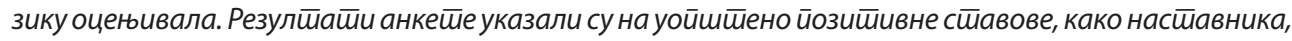
шако и ученика, ӣрема вршњачком очењивању, наравно, уз одређене резерве које суисйакнуйеура-

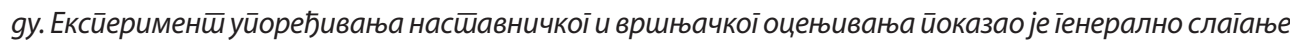

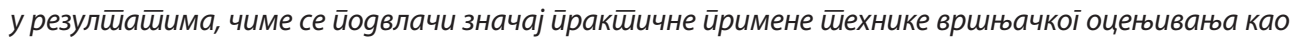

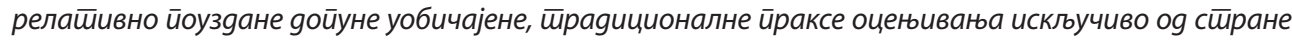
насйавника.
\end{abstract}

Кључне речи: енїлески као сйрани језик, сйавови насйавника и ученика, вршњачко очењивање.

\section{ОТНОШЕНИЕ ПРЕПОДАВАТЕЛЕЙ И УЧЕНИКОВ АНГЛИЙСКОГО КАК ИНОСТРАННОГО ЯЗЫКА К ОЦЕНКЕ СВЕРСТНИКОВ И СРАВНЕНИЕ РЕЗУЛЬТАТОВ ОЦЕНКИ РЕЧЕВОЙ КОМПЕТЕНЦИИ}

\begin{abstract}
Резюме Учитывая отсутствие исследований в области отношения преподавателей и учеников к оченке сверстников, а также возможности практического применения данного способа оценки в нашей школьной системе в преподавании английского как иностранного языка, данная работа направлена на изучение отношения сербских преподавателей и учеников к этой форме оченки, а также на сравнение результатов оченивания речевых навыков в разговорной речи. Преподаватели и ученики предварительно получили необходимые инструкции. Исследование состоит из трех частей: в первой части проведено анкетирование 112 преподавателей, во второй части 130 учащихся начальных и средних школ заполнили специально разработанную анкету. В третьей, экспериментальной части участвовали 24 ученика и 15 преподавателей в качестве экспертов по оченке и 5 учеников, чьи речевые навыки на иностранном языке были предметом оценки. Результаты исследования указывают на положительное отношение, как преподавателей, так и учеников к оченке сверстников, конечно, с определенной осторожностью, что особо подчеркивается в статье. Сравнительный анализ отметок преподавателей и сверстников показал общее совпадение результатов, что подчеркивает важность практического применения техники оценки сверстников как относительно надежного дополнения кобычной, традиционной практике оценивания исключительно со стороны учителей.
\end{abstract}

Ключевыеслова: английский как иностранный язык, мнение преподавателей и учеников, оченка сверстников. 